\title{
Finding your way through the science maze
}

\author{
Asifa Akhtar is Director at the Max Planck Institute of Immunobiology and Epigenetics. Her lab focuses on \\ chromatin and epigenetic regulation. A member of the European Molecular Biology Organisation, she received the \\ European Life Science Organization award in 2008 and the Wilhelm Feldberg Prize in 2017.
}

\section{Asifa Akhtar}

$\mathrm{M}$ any scientists live what can be considered as a cosmopolitan life, moving countries between career steps and attending conferences around the world. My introduction to this lifestyle started as a teenager, with my family's move from Karachi to Paris. This was a turning point for my academic outlook, but finishing high school did not come with a eureka moment about my future career; life seemed to hold many uncertainties. But education was my parents' highest priority, so I never felt the need to justify my eagerness to move from Paris to London for my university studies.

It was not until my summer project as a third-year biology student at University College London that I discovered my passion for science and the joy of doing experiments. Completing a $\mathrm{PhD}$ was definitely the way to go. Imperial Cancer Research Fund (now the Francis Crick Institute) in London was an ideal choice: apart from a centre for great science, it was also the only place where overseas students like me could afford to do their $\mathrm{PhD}$, since it offered stipends. I had the pleasure of training under the supervision of David Bentley and Richard Treisman. However, although I enjoyed my time as a PhD student, I had many disappointments and nagging doubts that I may not be good enough for a career in research.

Being an optimist, I decided to test myself in a different environment, and I moved to the European Molecular Biology Laboratory (EMBL) in Heidelberg, Germany, as a postdoctoral fellow in Peter Becker's lab. Moving to Germany may not appear easy if you do not speak the language but this was never a hurdle at the EMBL, a thoroughly international institute. My first year was, again, full of struggles until I changed projects for what was meant to be a trial period of two months - I have worked on this topic ever since! Regulation of the $\mathrm{X}$ chromosome to equalize expression of $\mathrm{X}$-linked genes between females and males poses an interesting epigenetic problem. A two-fold change in gene expression would appear to be a simple solution, yet it can make a difference between life and death, and involves complex molecular events between RNA, proteins and a specific target - the

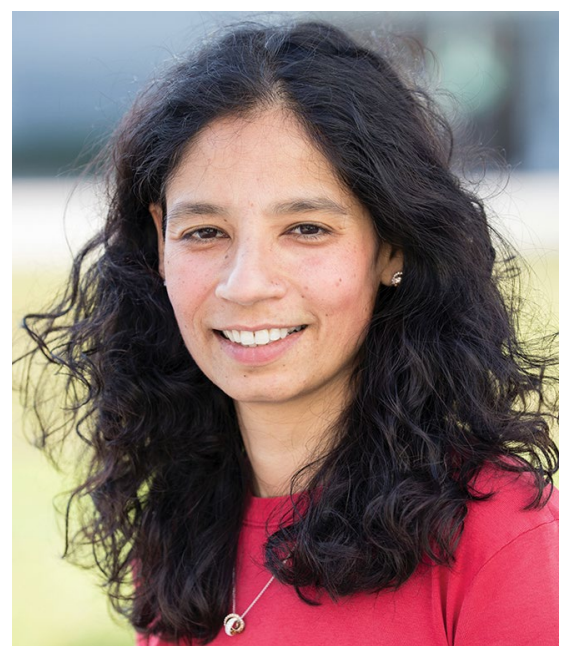

X chromosome. Even after decades of work we still do not understand everything. Like peeling an onion, there is always another level of knowledge to be gained. We are now getting into the exciting area of exploring which regulatory aspects have diversified and which have proven essential to pass through the evolutionary barrier in mammals.

My postdoc was very enjoyable, as I had developed sufficient experience and confidence to ask questions about everything and to not be satisfied by simply thinking 'I don't know'. I realized that I wanted to figure things out myself. However, as for many postdocs, I also wondered about my next career step. Becoming a group leader was an obvious move forward, but it appeared almost unachievable at the time. Yet, I went ahead and sent some applications, thinking that if I do not apply, then I will surely not get the job. And against all odds, I became a group leader at the EMBL. The scientific environment was thrilling and the positive energy was very motivating. Ian Mattaj, the current director general, was a great inspiration. The advice I received from day one was that I should tackle an important question rather than rush to publish. Such open and critical scientific discussions can broaden young minds and focus their research approach.

I may have been motivated as a postdoc, but there is nothing more motivating than leading a group and being responsible for people's careers. I really enjoyed my early group-leader years - the intense interaction in a small team was highly stimulating, as we all worked towards the same goals. This was extremely important as at the time I also had a child and was juggling running a lab and being a mum. Although I can relate to the pressure and uncertainties that come with both roles, I would advise young scientists not to compromise on their personal goals. A balanced home life can provide a different perspective to the very competitive and challenging realities of research. Scientific institutions should ensure that having worklife balance and raising a family is possible, for example by integrating childcare facilities in institutional planning. To enable equal opportunities we first need to take care of basic needs, which are required by all researchers regardless of gender.

My next move was to the Max Planck Institute of Immunobiology and Epigenetics, in Freiburg, where I am currently a director. This provided yet another level of responsibility that goes beyond the lab and requires managerial skills and strategic thinking. I am learning and enjoying this new facet of my life every day.

My career path may appear to be a smooth transition from one step to the next, but it has been a fight all along. There might be obstacles every step of the way, but my main advice for the younger generation is to never give up. A positive attitude can go a long way during hard times. Having a stable and supportive environment at work and at home is also essential in enabling a $\mathrm{PhD}$ student, postdoc or group leader to be creative and achieve their dreams. My advice is to choose a mentor and a life-partner carefully - the wrong choice in either can lead a bright young mind to drop off the research path.

\section{Asifa Akhtar \\ Max Planck Institute of Immunobiology and \\ Epigenetics, Freiburg, Germany. \\ e-mail:akhtar@ie-freiburg.mpg.de}

Published online: 28 August 2018

https://doi.org/10.1038/s41556-018-0175-3

Competing interests

The author declares no competing interests. 